\title{
Cornoside and other constituents from the latex of Parahancornia amapa (Hub.) Ducke (Apocynaceae) a medicinal plant in Northern Brazil
}

\author{
Mário G. de Carvalho, ${ }^{* 1}$ Luis A. de Albuquerque, ${ }^{1}$ Cássia C. F. Alves, ${ }^{1}$ Vera Cascon ${ }^{2}$ \\ ${ }^{1}$ Departamento de Química, Instituto de Ciências Exatas, Universidade Federal Rural do Rio de Janeiro, BR 465, \\ Km. 7, 23890-000 Seropédica-RJ, Brazil, \\ ${ }^{2}$ Fundação CINERJ, Rua Visconde de Niterói, 1364, Mangueira, 20943-001 Rio de Janeiro-RJ, Brazil
}

\begin{abstract}
RESUMO: “Cornosídeo e outros constituintes do látex de Parahancornia amapa (Hub.) Ducke (Apocynaceae) uma planta medicinal no Norte do Brasil”. O látex de Parahancornia amapa, popularmente conhecido como "leite do amapá” foi extraído com hexano, diclorometano e metanol. As frações obtidas com hexano e diclorometano forneceram misturas de 3-O-acillupeol e triterpenos confirmando resultados de estudos já realizados. No extrato metanólico identificou-se uma grande quantidade de mistura de carboidratos, metilmioinositol e derivados de feniletanóides tendo como principal constituinte o cornosídeo. Estes constituintes foram identificados através da análise de espectros de IV, RMN ${ }^{1} \mathrm{H}$ e ${ }^{13} \mathrm{C}$ e CG-EM das frações e do derivado acetilado do cornosídeo e do metilmioinositol.
\end{abstract}

Unitermos: Parahancornia amapa, amapa, feniletanóides, carboidratos, cornosídeo, ésteres de lupeol.

\begin{abstract}
Latex of Parahancornia amapa which is known as "amapa milk" in folk medicine was extracted with hexane, dichloromethane and methanol. From the hexane and dichloromethane were identified mixtures of 3-O-acyl lupeol esters such as identified previously. In the methanol extract, a large amount of carbohydrates, the phenylethanoid glucoside known as cornoside, other phenylethanoids derivatives and methylmyoinositol were identified. The analysis of IR, NMR and GC-LRMS of the natural compounds and tetra-acetylcornoside and comparison with literature data were used to identify the compounds.
\end{abstract}

Keywords: Parahancornia amapa, amapá, phenylethanoids, carbohydrates, cornoside, lupeol esters.

\section{INTRODUCTION}

Parahancornia amapa (Huber) Dicke (Apocynaceae) is a tree which occurs in the State of Amapá in the Brazilian Amazon region. It is commonly called "amapa milk", its latex is used in scars and bruises as plaster treatment, it is also mixed with honey, in equal quantities, to be used as a drink for treatment of asthma, bronchitis and physical weakness (Van den Berg, 1982). In the previous phytochemical study of this specie we reported the presence of sitosterol, stigmasterol, sitosterone, friedelin, lupeol, $\beta$-amyrin, $\alpha$-amyrin, their acetyl derivatives, besides $3 \beta-O$-acyl lupeol esters in bark, latex and roots of this plant (Carvalho et al., 2001; Sobrinho et al., 1991). These pentacyclic triterpenes, its acyl derivatives and the mixtures of four n-acyl-lupeol, four $3 \beta$-hydroxy-n-acyl lupeol and two $\beta, \delta$-dihydroxy$n$-acyl-lupeol were identified in the non-polar fractions of the latex from P. amapa (Sobrinho et al., 1991). In this paper we describe an additional study directing the identification of polar constituents in the latex from $P$. amapa. The presence of phenyletanoid glycoside and acyl lupeol esters in Parahancornia reveal biochemical metabolism different from Himatanthus (Barreto et al., 1998; Veloso et al., 1999; Abdel-Kader et al., 1997; Silva et al., 1998), Plumeria (Adam et al., 1979; Hamburger et al., 1991; Coppen \& Cobb, 1983; Kardono et al., 1990) and Allamanda (Coppen \& Cobb, 1983; AbdelKader et al., 1997) that have been identified as source of iridoids. On the other hand, it is in agreement with Jensen et al (2005) that cornoside often substitutes iridoid glucosides in plants where these are expected to be present. Considering that these kinds of compounds have been found in important herbal medicine (Teshima et al., 1996), these phenylethanoids and inositol can be the active compounds in the used polar fraction from the latex of P. amapa called as "amapa milk" by the folk medicine. An additional consideration is that the unadvised people substitute the latex from $P$. amapa with the one from Hmatanthus that has iridoids and sugars as polar compounds in its latex (Barreto et al., 1998). 


\section{MATERIAL AND METHODS}

\section{General procedures}

Melting points have not been corrected. IR spectra were recorded on a Perkin-Elmer 1605 FTIT spectrophotometer. ${ }^{1} \mathrm{H}(200.0 \mathrm{MHz})$ and ${ }^{13} \mathrm{C}(50.3$ $\mathrm{MHz}$ ) NMR spectra were recorded on a Brüker AC 200 spectrometer using DMSO- $\mathrm{d}_{6}, \mathrm{D}_{3} \mathrm{COD}$ or $\mathrm{CDCl}_{3}$ with TMS as internal standard. Electron Ionization Mass Spectra (LREI-MS) were taken with Gas Chromatograph coupled to a Mass Spectrometer (GC-MS) on a Varian Saturn 2000 using ion trap and 70 eV. Column chromatography with silica gel (Vetec and Aldrich 0.05-0.20 mm) and Sephadex LH-20 (Sigma, USA); for preparative TLC was used silica gel F254 G (Vetec), and silica gel TLC plates w/UV254, aluminum backed (Sorbent) were used to analyze the fractions collected from column chromatography (CC) with visualization under UV (254 and 366 nm), Lieberman-Burchard and/ or Godin reagents or exposure to iodine vapor.

\section{Plant material}

The used material was collected from one specimen identified by the botanist Benedito Vitor Rabello in State of Amapá, Brazil. The voucher specimen ( $n^{\circ}$ 07231) is deposited at the Herbário Amapaense (HAMAB) of the Divisão de Botânica do Museu Ângelo Moreira da Costa Lima, Instituto de Estudos e Pesquisas do Amapá (IEPA), Macapá-AP, Brazil.

\section{Extraction}

The dried latex (100.0 g) was extracted by maceration three times with hexane, dichloromethane and with methanol at room temperature. The solutions were obtained by filtration and the solvents were removed by distillation under vacuum to afford the residues PALAH (37.5 g), PALAD (30.0 g) and PALAM (25.0 g).

\section{RESULTS AND DISCUSSION}

The analysis of PALAH and PALAD by ${ }^{1} \mathrm{H}$ and ${ }^{13} \mathrm{C}$ NMR spectra and TLC plate revealed the presence of a mixture of pentacyclic triterpenes ( $\alpha$-amyrin, $\beta$-amyrin and lupeol), those acetyl derivatives and a complex mixture of acyl-lupeol esters identified previously (Carvalho et al., 2001; Sobrinho et al., 1991). The residue PALAM (15.0 g) was dissolved in methanol and submitted to Sephadex LH-20 column chromatography, eluted with methanol, to yield 40 fractions. The ${ }^{1} \mathrm{H}$ and ${ }^{13} \mathrm{C}$ NMR spectra of fractions $18-21$ (50.0 mg) collected from this column showed signals of glycopyranoside (1, identified in the fractions 22-24) together with signals compatible with other phenylethanoid derivatives such as $\mathbf{1 b}, \mathbf{2}, \mathbf{2 a}$, and $\mathbf{3}$. The GC-MS analysis of this group of fractions afforded a chromatogram whose analysis of each corresponding mass spectrum considering the main peaks let us to identify 1b [4-hydroxy-4-(2hydroxyethyl)-2,5-cyclohexadien-1-one; Rt: $4.36 \mathrm{~min}$; m/z(\%): 154 (100, $\mathbf{M}^{+}$), 135 (30), 123 (25), 108 (20), certainly yielded from 1]; 2 [ethanol-2-(ciclohexyl-1hydroxy-5-methoxy-2-en-4-one; Rt: 2,33 min; $\mathrm{m} / \mathrm{z}$ (\%): 186 (2, M+), 155 (20), 137 (34), 112 (31), 110 (33), 82 (100)] and 3 [4-hydroxyphenylethanol (tyrosol); Rt: $2.43 \mathrm{~min} ; \mathrm{m} / \mathrm{z}(\%): 138\left(40, \mathrm{M}^{+}\right), 121$ (17), 107 (100), 94 (5), 77 (33)]. The absence of corresponding peak of 2a let us to propose to be a derivative from 2 . The fraction 22-24 (gum, 2.0 g) was examined by IR, NMR spectra, including 2D-NMR experiments, besides mass spectrum and comparison with literature data (Khan et al., 1992) let to identify the quinol glucoside $\mathbf{1}$, known as cornoside (Jiménez and Riguera, 1994). 1 (50.0 mg) was treated with acetic anhydride and pyridine (1:1) at room temperature overnight, following usual work-up and filtration through a silica gel column, yielded the tetra-acetyl derivative 1a [m.p. 219-220 $\left.{ }^{\circ} \mathrm{C}, 40.0 \mathrm{mg}\right)$; ${ }^{1} \mathrm{H}$ NMR (CDCl, $\left.200 \mathrm{MHz}\right): 6.8$ (d, $\left.8.0 \mathrm{~Hz}, \mathrm{H}-3,5\right), 6.2$ (d, 8.0Hz, H-2,6), 4.9-5.2 (m, 2',3',4'), 4.60 (d, 8Hz, H-1') 4.0-4.3 (m, H-6'), 3,6 (m, H-5'); ${ }^{13} \mathrm{C} \mathrm{NMR} \mathrm{(CDCl}{ }_{3}$, 50.3 MHz): 188.0 (C-1), 169.3-169.5 $\left(\mathrm{OCOCH}_{3}\right), 147.8$ (CH-3,5), 128.6 (CH-2,6), 100.3 (CH-1'), 72.7 (CH-3’), 71.8 (CH-5'), 71.1 (CH-2'), 68.4 (CH-4'), $63.9\left(\mathrm{CH}_{2}-\right.$ 8), 61.9 (C-4), $61.7\left(\mathrm{CH}_{2}-6^{\prime}\right), 39.0\left(\mathrm{CH}_{2}-7\right), 24.1-24.7$ $\left.\left(\mathrm{OCOCH}_{3}\right)\right]$. The analysis of ${ }^{1} \mathrm{H}$ and ${ }^{13} \mathrm{C}$ NMR spectra of a solid material (300.00 mg), obtained from the fractions 27-31, revealed the presence of carbohydrate (4). 30.0 mg of 4 was acetylated by the same methodology used for $\mathbf{1}$ to obtain the derivative 4a. The analysis of IR and NMR spectra of $\mathbf{4 a}$, besides comparison with the same penta-acetyl derivative of carbohydrate isolated from Himatanthus articulata (Barreto et al., 1998) and from
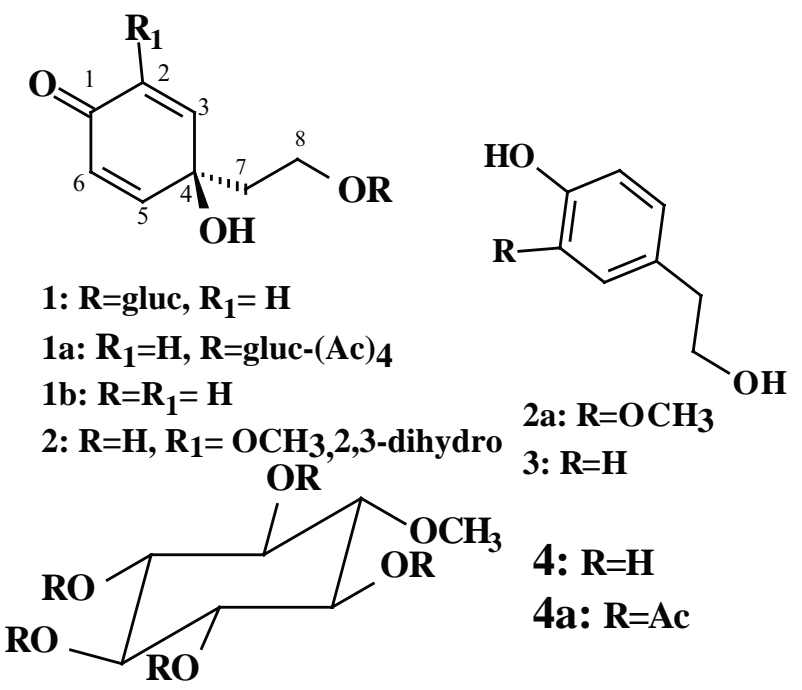

Figure 1. Chemical constituents from Parahancornia amapa. 
Ouratea hexasperma (Moreira et al., 1999), let us to identify 4 as methyl-myoinositol ( $\mathrm{mp} 214-217^{\circ} \mathrm{C}$ ). The ${ }^{13} \mathrm{C}$ NMR spectrum of the remaing fractions was analyzed and revealed the presence of carbohydrates mixture. This is the first record, in Apocynacae, of 1-3 which are widespread in families such as Cornacae, Oleacae, and Scrophulariacae (Kenichiro, 2005), Plantaginaceae (Jesen et al., 2005) and Bignoniaceae (Teshima et al., 1996) (Figure 1).

\section{ACKNOWLEDGEMENTS}

The authors thank CNPq, CAPES and FAPERJ for grants and financial support.

\section{REFERENCES}

Abdel-Kader MS, Wisse J, Evans R, van der Werff H, Kingston DGI 1997. Bioactive Iridoids and a new lignan from Allamanda cathartica and Himatanthus fallax from the Suriname Rainforest. J Nat Prod 60: 1294-1297.

Adam G, Khoi NH, Bergner C, Lien NT 1979. Plant growth inhibiting properties of plumieride from Plumeria obtusifolia. Phytochemistry 18: 1399-1400.

Barreto AS, Carvalho MG, Nery IA, Gonzaga L, Kaplan MAC 1998. Chemical constituents from Himatanthus articulata. J Braz Chem Soc 9: 430-434.

Carvalho MG, Velloso CRX, Braz-Filho R, Costa WF 2001. Acyl-lupeol esters from Parahancornia amapa (Apocynaceae). J Braz Chem Soc 12: 556-559.

Coppen JJW, Cobb AL 1983. The occurrence of iridoids in Plumeria and Allamanda. Phytochemistry 22: 125128.

Hamburger MO, Cordell GA, Ruangrungsi N 1991. Tradicional medicinal plants of Thailand XVII Biologically active constituents of Plumeira rubra. J Ethnopharmacol 33: 289-292.

Jensen SR, Albach DC, Ohno T, Grayer RJ 2005. Veronica: iridoids and cornoside as chemasystematic markers. Biochem Syst Ecol 33: 1031-1047.

Jiménez C, Riguera R 1994. Phenylethanoid glycosides in Plants: Strututes and biological activity. Nat Prod Rep 11: 591-606.

Kardono LBS, Soefjan T, Padmawinata K, Pezzuto JM, Kinghorn AD 1990. Cytotoxic constituents of the bark of Plumeria rubra collected in Indonesia. $\mathrm{J} \mathrm{Nat}$ Prod 53: 1447-1455.

Kenichiro I 2005. Citochrome P450 enzimes in biosyntheses of some plant secondary metabolites. Yakugaku Zasshi 125: 31-49.

Khan AI, Erdelmeier CAJ, Sticher O 1992. New phenolic glucosides from the leaves of Eurya tigang. $\mathrm{J}$ Nat Prod 55: 1270-1274.

Moreira IC, Carvalho MG, Bastos ABFO, Braz-Filho R 1999. A flavone dimer from Ourtea hexasperma. Phytochemistry 51: 833-838.

Silva JRA, Rezende CM, Pinto AC, Pinheiro MLB, Cordeiro MC, Tamborini E, Young CM, Bolzani VS 1998. Éster triterpênicos de Himatanthus sucuuba (Spruce) Woodson. Quim Nova 21: 702-704.

Sobrinho DC, Hauptli MB, Appolinário EV, Kollenz CLM,
Carvalho MG, Braz-Filho R 1991. Triterpenoids isolated from Parahancornia amapa. J Braz Chem Soc 2: 15-20.

Teshima K, Kaneko T, Ohtani K, Kasai R, Lhieochaiphant S, Yamasaki K 1996. Phenylethanoids and ciclohexylethanoids from Oroxylum indicum. $\mathrm{J}$ Nat Med 50: 307.

Van den Berg ME 1982. Plantas Medicinais na AmazôniaContribuição ao Seu Conhecimento Sistemático. CNPq/PRU/MPEG, Belém-PA, Brasil.

Veloso MP, Nagem TJ, Oliveira TT 1999. $\beta$-Dihidroplumericinic acid from Himatanthus phagedaenicus. Biochem Syst Ecol 27: 669-671. 